\title{
Typological Comparison of Relativization in Amharic and Ezha
}

\author{
Endalew Assefa \\ Addis Ababa University, Ethiopia
}

\begin{abstract}
This article describes the structure of relative clauses in the Amharic and Ezha Languages thereby making typological comparison between the two languages. Both headed and headless relative clauses are attested in both languages. A headed relative clause in both languages is found to be prenominal as the clause precedes the head noun that is to be modified. With reference to both headed and headless relative clause types, constituents which relate to a subject, direct and indirect object, oblique, and possessor noun are found to be relativized in the target languages. By so doing, Amharic employs the relativizer $j$ - in perfective conjugations, while it makes
\end{abstract}

\footnotetext{
Endalew Assefa

Assistant Professor of Linguistics, Addis Ababa University, Ethiopia

Email: endexye2006@gmail.com
}

Received 16 January, 2019; Revised 12 February, 2019; Accepted 7 August, 2019

Copyright @ 2019 Language Research Institute, Sejong University Journal of Universal Language is an Open Access Journal. All articles are distributed online under the terms of the Creative Commons Attribution Non-Commercial License (http://creativecommons.org/licenses/by-nc/3.0) which permits unrestricted non-commercial use, distribution, and reproduction in any medium, provided the original work is properly cited. 
use of imm- to relativize imperfective verbs. On the other hand, Ezha uses $j \partial$ - in the relativization of perfective structures, whereas it employs no overt morpheme to relativize imperfective verbs, hence, zero marking. Unlike Amharic, Ezha employs no overt relativizer on negative relative verbs. The relativized constituents of headless relative clauses in both languages are traceable as they can be recovered by considering the agreement suffixes attached to the respective relative verbs.

Keywords: relativization, relativizer, head, pre-nominal relative clause, headless relative clause

\section{Introduction}

Both Amharic and Ezha belong to the South Ethio-Semitic language sub-phylum under the Ethio-Semitic language phylum. Within the South Ethio-Semitic, Amharic assumes the Transversal South EthioSemitic family, while Ezha belongs to the Outer South Ethio-Semitic sub-class (Hetzron 1977).

The Amharic language is natively spoken in the Amhara region of the country (Ethiopia), i.e. Gojjam, Gonder, Wello and Shewa. Besides, it is predominantly spoken in Addis Ababa, the country's capital, in addition to other regions where the language is spoken as a second language by non-Amharas and as a native language by Amhara migrants. Note also that Amharic serves as a working language for the federal government of Ethiopia and as a lingua franca in virtually all parts of the country. The number of its native speakers counts approximately 17.5 million plus, and roughly other 5 million plus people speak it as a second language (Grimes 2003, Meyer 2011).

On the other hand, Ezha is typically spoken in and around the Agenna town within the Gurage administrative zone of the Southern Nations, Nationalities, and Peoples Regional State (SNNPR) of 
Ethiopia. The area where Ezha is spoken is bordered to the north-east by Muher, to the south-west by Chaha and to the east by Gumer (Assefa 2014).

This article provides a descriptive account of relative clauses in the two languages: Amharic and Ezha. Relativization phenomena in these languages have been presented by way of making typological comparisons. According to Payne (1997), a relative clause is a dependent clause that functions as a nominal modifier. The pertinent parts of a relative clause include the head (the noun phrase that is modified by the clause), the restricting clause (the relative clause itself), and the relativizer (the morpheme or particle that sets off the restricting clause as a relative clause).

There are several typological parameters by which relative clauses can be grouped. The major typological criterion by which relative clauses can vary is the position of the clause with respect to the head. Accordingly, relative clauses can be prenominal (the clause occurs before the head), postnominal (the clause occurs after the head), internally headed (the head occurs within the relative clause), or they may be headless (Payne 1997).

de Vries (2001) also states that a relative clause is subordinated and is connected to surrounding material by a pivot constituent. The pivot is often a noun phrase which refers to a constituent semantically shared by the matrix clause and the relative clause. If the pivot appears to be spelled out inside the matrix clause, it can be recognized as an antecedent where the relative clause contains a gap (which may be filled by a relative pronoun). However, if the pivot is spelled out inside the relative clause, the construction is head internal. In this case the matrix contains the gap, which is filled by the whole relative construction or by a demonstrative (a correlative construction).

Another universal property of relative clauses relates to the fact that the semantic $\theta$-role and syntactic role that the pivot constituent has in 
32 Typological Comparison of Relativization in Amharic and Ezha

the relative clause, are in principle independent of its roles in the matrix clause. For example, in the structure 'The thief that I caught yesterday was anxious', the thief is the pivot NP, and it is an experiencer in the main clause but patient in the relative clause. Syntactically, it is a subject in the main clause but direct object in the subordinate clause. Hence, the gap in the relative representing the thief is both semantically and syntactically independent of its roles in the main clause.

However, every semantic and/or syntactic role may not be available in every language. Languages can restrict the number of available internal roles, i.e. they can be scaled differently on a grammatical function hierarchy (Keenan \& Comrie 1977). For instance, in many languages prepositional objects and lower functions are not possible relative positions. There are also language-dependent constraints that have to do with the possibility of recovering the function of the relative 'gap'. Nevertheless, these limitations do not fundamentally alter the role independency stated above (Givon 1984).

In light of the articulations made by the aforementioned scholars, the following subsequent sections of this article try to examine as to how relative clauses in Amharic and Ezha behave in a comparative manner. The analyses are informed by assumptions of typological and descriptive linguistics as stipulated by Payne (1997) without considering any particular theoretical framework. The Amharic data for the study were collected through introspection since the researcher himself is a native speaker of the language. Whereas, Ezha data have been accessed by consulting native speakers. In this case, elicitation has been employed as a major tool supplemented by recording of free narratives. Regarding the data presentation, both phonetic and phonemic transcription are employed using IPA; whenever there occur differences between phonetic and phonemic forms, a four-line interlinear glossing scheme has been followed. 


\section{Description of Relativization in Amharic and Ezha}

As is the case in most Ethio-Semitic languages such as Tigrigna (Mazengia 2015), Argobba (Amare 2009), Wolane (Meyer 2006) and so on, Amharic and Ezha exhibit an SOV word order in the prototypical (canonical) declarative structures as in kasa dabbo bolla (Amharic) and kasa dabbo bənnam (Ezha) to mean 'Kasa ate bread' in both languages. In the structures, the subject kasa refers to a masculine proper name and the object noun dabbo stands for 'bread' followed by the verbs balla and bonnam 'ate' in the respective languages.

When it comes to relativization, only indicative verbs (perfective and imperfective) can be relativized in both Amharic and Ezha; jussive and imperative forms cannot be turned into relatives. In both languages, both headed and headless relative clauses are attested of which the former is found to be prenominal in both languages as the clause precedes the head noun that is to be modified. These languages are typologically characterized by the absence of relative pronouns. In the Amharic language, the relative verb in perfective structures makes use of the prefix jo-for a relativization purpose, while imperfective verbs employ the relativizer imm-. In Ezha, on the other hand, the relative verb in the perfective conjugation employs the relativizing prefix jo-, while imperfective verbs render relative readings without any overt marker, hence, zero marking. Let us consider the following examples. 
34 Typological Comparison of Relativization in Amharic and Ezha

(1) Amharic
a. askala ja-gaggar-attf-iw
dabbo
Askale REL-bake.PFV-3FS.Sj-3MS.Oj bread
bot'am t'afats' now
very sweet COP.PRES ${ }^{1}$

'The bread that Askale baked is very sweet.'

b. naga imm-j-mat'a-u-n

tomorrow REL-3MS-come.IPFV-DEF-ACC

lid3 mawak' i-fallig-alla-hu

boy know.VN 1S-want.IPFV-AUX.PRES-1S.Sj

'I want to know the boy who will come tomorrow.'

(2) Ezha
a. gonts-we hyena-DEF

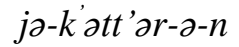 REL-kill.PFV-3MS.Sj-3MS.Oj wattaddar nikk'ar gobaz- $u^{2}$ soldier very brave-COP.PRES.3MS
'The soldier who killed the hyena is very brave.'

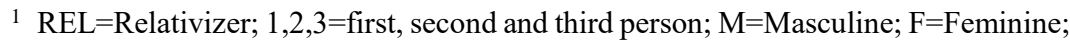
$\mathrm{S}=$ Singular; $\mathrm{COP}=$ Copula; $\mathrm{PRES}=$ Present; $\mathrm{PFV}=$ Perfective, $\mathrm{IPFV}=$ Imperfective; $\mathrm{DEF}=$ Definite; $\mathrm{ACC}=$ Accusative; $\mathrm{VN}=$ Verbal noun; $\mathrm{Sj}=$ Subject; $\mathrm{Oj}=\mathrm{Object}$; AUX=Auxiliary.

2 The Amharic equivalent is:
$d z i b-u-n$
ja-gaddal-a-w wattaddar
bat'am gobaz now
hyena-DEF-ACC
REL-kill.PFV-3MS.Sj-3MS.Oj very
brave COP.M.PRES 


\section{b. jo-dəsta t-agəba-n \\ ACC-Desta 3FS-marry.IPFV-3MS.Oj \\ garad markamma-n-ja \\ girl beautiful-COP.PRES-3FS \\ 'The girl who is going to marry Desta is beautiful.'}

Structures (1a) in Amharic and (2a) in Ezha involve perfective verbs. In both cases, the relative verbs carry the relativizing prefix jathereby depicting the fact that the two languages employ the same form to mark relativization in the perfective. By contrast, (1b) in Amharic and (2b) in Ezha apparently indicate that the relative verbs are in their imperfective conjugations. In this case, Amharic uses the relativizer imm-, whereas Ezha does not employ any overt relative clause marker. This implies that the two languages appear to be divergent from each other in terms of marking relative clauses in the imperfective. Notice also that no accusative marker is attached to the definite direct object noun phrase in (2a) of Ezha unlike the case in (1a) of Amharic and (2b) of Ezha. This is due to the fact that the accusative morpheme in Ezha does not appear on non-human object nouns (Assefa 2014, 2017). It is also worth noting that, as can be clearly seen from the above structures, in both languages, the relative clauses precede the nouns to be modified; hence, both languages involve typologically pre-nominal relative clauses. Once again, in both languages, the relative verbs appear as the last constituents in the corresponding relative clauses and show concord with the respective head nouns.

In negative relative clauses, the relativizer in Amharic occurs

3 The Amharic equivalent is:
dosta- $n$
imm-t-agaba-w
lidzagarad k'onjo nat
Desta-ACC REL-3FS-marry.IPFV-3MS.Oj girl
beautiful COP.F.PRES 
preceding the negative marker as indicated in (3a) and (3b). However, Ezha behaves in a completely different way in this regard; the relativizer never appears with negative verbs. Even the one which overtly surfaces in affirmative perfective conjugations disappears when the relative verb is turned into negative. Hence, the negation marker attaches itself directly to the verbal base in the perfective as in (4a) and preceding the person prefix in the imperfective as indicated in (4b) since the relativizer is not in place in both cases.

(3) Amharic

a. mas'af

ja-al-anabbab-ə-w

lids

book

REL-NEG ${ }^{4}$-read.PFV-3MS.Sj-DEF boy

'The boy who did not read the book'

b. hisab imm-a-j-wadd-ə-w

tomari

Maths REL-NEG-3MS-like.IPFV-3MS.Sj-DEF student

'The student who does not like Maths'

(4) Ezha

a. $3 a b b \quad a n-k$ 'วt'วr-ว-we miss

lion NEG-kill.PFV-3MS.Sj-DEF man

'The man who did not kill a lion'

b. $3 a b b \quad e k$ 'วt'rwe

miss

zabb

$a-j-k$ 'ot'r-we

miss

lion

NEG-3MS-kill.IPFV-DEF

man

'The man who will not kill a lion'

4 NEG=Negative

5 The Amharic equivalent is:

anbəssa ja-al-gaddal-ə-w [jalgaddələw] səw

lion REL-NEG-kill.PFV-DEF man 
Regarding the Amharic relativizer in the imperfective, it is not uncommon to hear people, especially in towns, articulating the form jamm- instead of imm- as in naga jammimat'aw sawijje ... as opposed to naga immimat'aw sawijje ... to refer to the same reading: 'the man who will come tomorrow ...' (see also Meyer 2011). However, the former seems to be a recent development, and hence, unoriginal, since typical Amharic speakers dwelling in the exotic Amhara rural settings adhere to the latter. This claim can be evidenced by the fact that even in towns only imm- but not jamm-can surface in situations where a relational prefix precedes the relativizer in the imperfective. Hence, structure (5a) is acceptable, while (5b) is ill-formed.

$$
\begin{aligned}
& \text { a. kəsə?at bə-imm-j-mət'a-ə-w } \\
& \text { afternoon INST }{ }^{6} \text {-REL-3MS-come.IPFV-3MS.Sj-DEF } \\
& \text { makina i-hed-all-əhu } \\
& \text { car 1S-go.IPFV-AUX.PRES-1S.Sj }
\end{aligned}
$$

car 1S-go.IPFV-AUX.PRES-1S.Sj

In the target languages, it is possible to relativize a subject, an object (both direct and indirect), an oblique constituent and a possessor noun. These relativization phenomena are discussed one after the other in the following sub-sections.

\footnotetext{
${ }^{6}$ INST=Instrument
} 


\subsection{Subject Relativization}

In both Amharic and Ezha, a noun phrase that functions as the subject of a sentence can be modified by a relative clause, hence, subject relativization.

a. Amharic

$$
\begin{array}{ll}
\text { məs'af-u- } n & \text { jə-k'əddəd-ə-w } \\
\text { book-DEF-ACC } & \text { REL-tear.PFV-3MS.Sj-3MS.Oj } \\
\text { lids } & \text { tə-gərrəf-ə } \\
\text { boy } & \text { PASS }^{7} \text {-whip.PFV-3MS.Sj } \\
\text { 'The boy who tore the book was whipped.' }
\end{array}
$$

b. Ezha

$$
\begin{array}{ll}
\text { zabb-we } & \text { ja-k'att'ar-ə-n } \\
\text { lion-DEF } & \text { REL-kill.PFV-3MS.Sj-3MS.Oj } \\
\text { wattaddar } & \text { țannว-ə-m }{ }^{8} \\
\text { soldier } & \text { come.PFV-3MS.Sj-CM }{ }^{9} \\
\text { 'The soldier who killed the lion came.' }
\end{array}
$$

In these expressions, the relativized noun phrases in both Amharic and Ezha are the subjects of the respective relative clauses. The relative clauses are meant to modify the respective head nouns restrictively, i.e. they delimit the potential referential scope of the head nouns. In (6a), for instance, the Amharic relative clause mas'afun jak'addadəw 'the one who tore the book' restricts the potential

\footnotetext{
7 PASS=Passive

8 The Amharic equivalent is: anbassa-w- $n$ ja-gaddal-ə-w wattaddər matt'a-ə [matt'a] lion-DEF-ACC REL-kill.PFV-3MS.Sj-3MS.Oj soldier come.PFV-3MS.Sj

${ }^{9} \mathrm{CM}=$ Clause Marker
} 
reference of the generic noun lidz 'boy' to a very specific one, i.e. the one who tore the book. Similarly, in (6b), the Ezha relative clause zabbiwe jak $k^{w} \partial t t$ ' $\partial r \partial n$ 'the one who killed the lion' restricts the possible referential scope of the noun wattaddar 'soldier' to a very specific entity, i.e. the one who killed the lion. In both cases, the relativizer appears to be jo-since the relative verbs are in their perfective forms.

The above structures vividly show that the subject constituents in both languages do not overtly appear in their canonical positions within the relative clauses; they are indicated by the subject agreement affixes attached to the respective relative verbs. In Amharic, for instance, if the subject noun lid 3 'boy' were to appear in its canonical slot, the structure would read as *lidz mas'afun jakaddadaw lidz which literally means 'boy who tore the book the boy'. However, since such a structure is un-natural in the language, the noun lid 3 'boy' is omitted from its original slot, which is the initial position of the relative clause, and is simply referred to by the 3MS subject agreement suffix - 2 that is attached to the relative verb $k$ 'addad- 'tear'. Exactly the same operation applies to Ezha; the head noun wattaddar 'soldier' cannot explicitly assume the initial position of the given clause since such a configuration results in an ungrammatical structure. The noun is referred to by the $3 \mathrm{MS}$ subject agreement marker - - attached to the relative verb $k$ ' $\partial t t$ ' $\partial r$ - 'kill'.

Both of the structures (6a) and (6b) depict that there are object agreement suffixes ( $-w$ in Amharic and $-n$ in Ezha) attached to the respective relative verbs. This is not, however, always the case in subject relativization. The suffixes per se occur only when the object noun phrases are definite. In both languages, indefinite object noun phrases do not trigger object agreement suffixes to appear on the relative verb. The following structures demonstrate this point. 
40 Typological Comparison of Relativization in Amharic and Ezha

(7) a. Amharic
mas'af jak'addadow
lid 3 matt'a
mas'af ja-k'addad-ə-u
lids matt'a-a
book REL-tear.PFV-3MS.Sj-DEF boy come.PFV-3MS.Sj
'The boy who tore a book came.'

b. Ezha

$\begin{array}{lll}\text { zabb } & \text { ja-k'ətt'or-ə-we } & \text { wattaddar } \\ \text { lion } & \text { REL-kill.PFV.3MS.Sj-DEF } & \text { soldier } \\ n i k k ' a r & \text { gobəz- } u^{10} & \\ \text { very } & \text { brave-COP.PRES.3MS } & \\ \text { 'The soldier who killed a lion is very brave.' }\end{array}$

In the Amharic example, i.e. (7a), the phonetic realization of the definite morpheme, i.e. $-w$ is identical to that of the 3MS.Oj suffix indicated in (6a). However, in the strict sense, the suffix $-w$ in (7a) is underlyingly $-u$ as indicated in the second line of the data presentation, and has nothing to do with object marking. It is rather the definite marker that canonically attaches to the head noun lid 3 'boy' as in the non-relativized counter part of (7a) which would read as lidzu mas'af $k$ 'addada 'the boy tore a book'.

\subsection{Object Relativization}

Like subject noun phrases, direct and indirect object noun phrases are found to be relativized in both Amharic and Ezha. In this case, in

10 The Amharic equivalent is:

\begin{tabular}{|c|c|c|}
\hline ssa & jə-gəddəl-ə-w & wattaddar \\
\hline lion & REL-kill.PFV-3MS.Sj-DEF & soldier \\
\hline bat'am & gobaz & \\
\hline & COP.M.PRES & \\
\hline
\end{tabular}


both languages, the relative verbs obligatorily carry object agreement suffixes (in addition to subject markers), which agree with the relativized objects as demonstrated in the following examples.

(8) Amharic

a. indalaw ja-gazza-ว-w

Endalew REL-buy.PFV-3MS.Sj-3MS.Oj

tS'amma tə-k'วddad-ə

shoe PASS-tear.PFV-3MS.Sj

'The shoe that Endalew bought is torn.'

b. askala dabdabbe ja-lak-ətț-ill-ət

Askale letter REL-send.PFV-3FS.Sj-APPL-3MS.Oj

lid3 wandimm-e naw

boy brother-1S.POSS COP.PRES ${ }^{11}$

'The boy to whom Askale sent a letter is my brother.'

(9) Ezha

a. s'əxaj jə-sijo-ttf-in

Tsehay REL-buy.PFV-3MS.Sj-3MS.Oj

$t^{\prime} a j \quad a 33 \partial-x^{w}-n-m^{12}$

sheep see.PFV-1S.Sj-3MS.Oj-CM

'I saw the sheep that Tsehay bought.'

11 APPL=Applicative; POSS=Possession

12 The Amharic equivalent is:

$s$ 'əhaj ja-gazza-ttf-iw- $n$

bag ajja-hu-t

Tsehay REL-buy.PFV-3FS.Sj-3MS-OJ-ACC sheep see.PFV-1S.Sj-3MS.Oj 
42 Typological Comparison of Relativization in Amharic and Ezha

b. dosta mas'af jə-nax-ə-r-əma

Desta book REL-send.PFV-3MS.Sj-BENF-3FPL ${ }^{13}$.Oj

gred aganna-nija ${ }^{14}$ war-əma-m

girl.PL Agenna-GOAL go.PFV-3FPL.Sj-CM

'The girls to whom Desta sent a book went to Agenna.'

The relativized positions in (8a) of Amharic and (9a) of Ezha are occupied by the direct object noun phrases, while in (8b) of Amharic and (9b) of Ezha it is indirect object noun phrases which are relativized. The direct and the indirect object noun phrases are not overt within the respective relative clauses; they are recoverable by accounting for the object agreement suffixes attached to the relative verbs.

In the case of Amharic, the suffix $-w$ of the relative verb in (8a) agrees with the relativized direct object noun phrase tS'amma 'shoe', while the suffix - $\partial t$ of the relative verb in (8b) exhibits concord with the indirect object noun phrase lidj 'boy' which is relativized. Similarly, in the Ezha examples, the suffix $-n$ in (9a) agrees with the relativized direct object noun, i.e. $t$ ' $a j$ 'sheep, whereas the applicative $-r$ together with the suffix - $ә m a$ in $(9 b)$ refers to the relativized indirect object noun gred 'girls'.

As hinted above, in both languages, unlike the case in non-relative verbs where the object agreement suffixes are optional, relative verbs whose object constituents are relativized obligatorily bear object agreement suffixes. Otherwise, the constructions turn out to be ungrammatical.

13 PL=Plural

14 The Amharic Equivalent is:

$\begin{array}{llll}\text { dasta } & \text { mos'haf } & \text { ja-lak-ə-ll-attow } & \\ \text { Desta book } & \text { REL-send.PFV-3MS.Sj-BENF-3PL.Oj } \\ \text { lidzagarad-ottf } & \text { wadə-aganna } & \text { hed-u } \\ \text { girl-PL } & \text { GOAL-Agenna go } & \text { PFV-3PL.Sj }\end{array}$


It is also worth noting that in (8a) of Amharic and (9a) of Ezha, the direct object noun phrases are not marked for definiteness although the respective verbs (both the relative and the main verbs) bear direct object agreement suffixes which presuppose definite object nouns if the accusative object nouns were not modified by a relative clause (as in the Amharic structure: indalaw tr'ammawn gazzaw 'Endalew bought the shoe' where $-u>-w$ which appears preceding the terminal suffix of the direct object noun tf'ammawn 'the shoe' is the definite marker; and in the Ezha expression: s'axaj t'ajwe sijatt/in 'Tsehay bought the sheep' where -we of the direct object noun t'ajwe 'the sheep' marks definiteness).

\subsection{Oblique Relativization}

An oblique constituent is the one which does not encode a core grammatical relation to the verb, i.e. it is not an argument of a clause (Payne 1997). Oblique constituents in Amharic and Ezha can occupy the relativized positions of relative clauses. In both languages, oblique relativization relates to the relativization of adpositional phrases that render different adverbial functions such as spatial location, temporal location, instrument and purpose, as well as complementation of motion verbs.

(10) Amharic

$\begin{array}{llll}\text { a. } \text { aseffa } & \text { zaf } & \text { jə- } k^{\prime} \text { 'orrot'-ə-bb-ət } \\ \text { Assefa } & \text { tree } & \text { REL-cut.PFV-3MS.Sj.APPL.3MS } \\ \text { missar } & \text { bət'am } & \text { silat } & n \partial w \\ \text { ax } & \text { very } & \text { sharp } & \text { COP.PRES }\end{array}$

'The ax by which Assefa cut a tree is very sharp.' 
44 Typological Comparison of Relativization in Amharic and Ezha

b. indalaw ja-hed-ə-bb-ət

$\begin{array}{llll}\text { Endalew } & \text { REL-go.PFV-3MS.Sj-APPL-3MS } \\ \text { agar } & \text { bat'am } & \text { ruk' } & \text { now } \\ \text { country } & \text { very } & \text { far } & \text { COP.PRES }\end{array}$

'The country where Endalew went is very far.'

(11) Ezha
a. wattaddar-we
zabb-iwe
$j \partial-k^{\prime} \partial t t^{\prime} \partial r-\partial-\beta^{w-}-\partial$
soldier-DEF
lion-DEF
REL-kill.PFV-APPL-3MS
gumma $^{15}$
ta-sabbar-a-m
stick
PASS-break.PFV-3MS-CM
'The stick by which the soldier killed the lion is broken.'

b. dəsta

$$
\text { ja-gabba- } \beta^{w}-a
$$

bet

Desta

REL-enter.PFV-APPL-3MS

house

$x^{w}$ ett

fink ${ }^{\prime j}$

nara- $n^{16}$

two

door

exist-3MS.Oj

'The house to which Desta entered has two doors.'

The Amharic relative verbs in (10a) and (10b) carry the applicative $-b b$ followed by a $3 \mathrm{MS}$ suffix $-a t$ together referring to the relativized adpositional phrases whose underlying forms are arguably bəmissar

15 The Amharic equivalent is:
wattaddar-u
anbassa-w-n
ja-gaddal-a-bb-at
soldier-DEF lion-DEF-ACC
REL-kill.PFV-3MS.Sj-APPL-3MS
dulla ta-sabbar-a
stick PASS-break.PFV-3MS
16 The Amharic equivalent is:
dosta ja-gabba-ว-bb-ət
Desta REL-enter.PFV-3MS.Sj-APPL-3MS.Oj
bet hulatt bar alla-w
house two door exist-3MS.Oj 
'by an ax' and bəməkina 'by a car' in their respective order. In a similar vein, the relative verbs of the Ezha structures given in (11a) and (11b) possess the instrumental marker $-\beta^{w}$ followed by the $3 \mathrm{MS}$ suffix - $\partial$ referring to the relativized adpositional phrases that could have evidently appeared as bəgumma 'by a tick' and betnija 'towards the house' if they were not to be modified by relative clauses.

In the structures of both Amharic and Ezha given above, the relativized adpositional phrases are missing within the respective relative clauses; they can only be retrieved by tracing the applicative morphemes which are meant to signal that the heads of the relative clauses are oblique elements. In (10a) of Amharic and (10c) of Ezha, the relativized constituents pertain to oblique relatives rendering adverbial readings, i.e. instrument (bəmissar 'by an ax' and bəgumma 'by a stick' respectively). On the other hand, the heads of the relative clauses in (10b) of Amharic and (11b) of Ezha are related to complement adpositional phrases since they are presupposed constituents by the respective motion verbs involved in the modifying relative clauses; they designate the places where the movement denoted by the relative verbs (jahedabbət of Amharic and jagabba $\beta^{w} \partial$ of Ezha) is assumed to terminate.

\subsection{Possessor Noun Relativization}

Genitive constructions can also be relativized in both Amharic and Ezha. In this case, it is the possessor noun of the genitive noun phrase that can be the head of a relative construction. In relativized genitive structures of both languages, the genitive markers do not appear overtly; the genitive reading is preserved by possessive suffixes attached to the possessed nouns as illustrated by the following examples. 
(12) a. Amharic bəre- $u \quad$ ja-t'əffa-ə- $b b-\partial t$ ox-3MS.POSS REL-disappear.PFV-3MS.Sj-APPL-3MS gabere bat'am habtam naw farmer very rich COP.PRES

'The farmer whose ox disappeared is very rich.'

b. Ezha

$$
\begin{aligned}
& \text { mas'af-ota ja-tə-gaddəd-ə- } \beta^{w} \text {-ə } \\
& \text { book.3MS.POSS REL-PASS-tear.PFV-3MS.Sj-APPL.SMS } \\
& \text { aridd3 gobəz təmari- } u^{17} \\
& \text { boy brave student-COP.3MS } \\
& \text { 'The boy whose book is torn is an intelligent student.' }
\end{aligned}
$$

In these structures, gabəre 'farmer' of Amharic and aridd 3 'boy' of Ezha are the possessor nouns; they are relativized and become the heads of the respective relative clauses. The nouns bore 'ox' of Amharic and mas'af 'book' of Ezha, on the other hand, are the possessed nouns which bear the 3MS possessive suffixes $-u$ and -ota in their respective order. These possessive suffixes are meant to complement the genitive prefixes that do not appear in the structures, which would apparently surface if the head nouns were not modified by relative clauses (as in the Amharic expression: jagaborew bare t'affa 'The farmer's ox disappeared', and of the Ezha structure: jariddziwe mas'af tagaddadam 'the boy's book is torn' where the

\footnotetext{
17 The Amharic equivalent is:

mas'haf-u

book-DEF

lids gobaz

boy clever

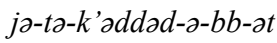

REL-PASS-tear.PFV-3MS.Sj-APPL-3MS.Oj

tomari now

student COP.M.PRES
} 
initial prefix ja- in both cases marks genitive). The occurrence of the possessive suffixes guarantees the relative constructions of both languages to denote a possessor-possessed relationship between the two nouns involved in the genitive configurations per se (gabare 'farmer' and bore 'ox' in Amharic, and tamari 'student' and mas'af 'book' in Ezha).

In addition to headed relative clauses discussed thus far, which are characterized by an overt realization of the heads (modified nouns), both Amharic and Ezha have non-headed relative clauses as well, which do not have overtly realized heads. The heads of such relative clauses in both languages can be recovered by taking the agreement affixes attached to relative verbs into consideration. The relativized elements in both Amharic and Ezha could be subject noun phrases as in (13a) and (14a), object noun phrases as in (13b) and (14b) or oblique constituents as in (13c) and (14c).

(13) Amharic

a. lidz-otț-e-n child-PL-1S.POSS-ACC imm-j-makr-ill-inn-in REL-3MS-advise.IPFV-APPL-1S.Oj-ACC akəbr-all-əhu respect.IPFV-AUX.PRES-1S

'I respect (the one) who advises my children'

b. askalo ja-balla-tts-w- $n$

Askale REL-eat.PFV-3FS.Sj-3MS.Oj-ACC awk'-all-əhu know.IPFV-AUX.PRES-1S

'I know what Askale ate.' 
c. indalawja-hed-ə-bb-ət

EndalewREL-go.PFV-3MS.Sj-APPL-3MS

al-ta-awwak'-ə-m

NEG-PASS-know.PFV-3MS-CM

'The (place) where Endalew went is not known.'

(14) Ezha

a. jə-dəsta jə-k'ətt'ər-ə-n

ACC-Desta REL-kill.PFV-3MS.Sj-3MS.Oj

a3zว- $x^{w}-n-m^{18}$

see.PFV-1S.Sj-3MS.Oj-CM

'I saw (the one) who killed Desta.'

b. dəsta jə-k'วtt'วr-ว-n

Desta REL-kill.PFV-3MS.Sj-3MS.Oj

samma- $x^{w}-m$

hear.PFV-1S-CM

'I heard about what Desta killed.'

c. abza ja-war-ə- $\beta^{w}-\partial$

Abza REL-go.PFV-3MS-APPL-3MS

$o d-x^{w}-i n-m$

tell.PFV-1S.Sj-3MS.Oj-CM

'I told him where Abza went.'

None of the relative clauses given in $(13 a-c)$ and $(14 a-c)$ possesses an overt head noun. The agreement elements attached to the relative

18 The Amharic equivalent is:
dosta-n
ja-gaddal-a- $w-n$
ajja-hu- $t$
Desta-ACC REL-kill.PFV-3MS.Sj-3MS-Oj-ACC
see.PFV-1S.Sj-3MS.Oj 
verbs denote that the heads relate to a third person masculine singular noun. In (13a) of Amharic and (14a) of Ezha, the subject affixes $j$ - and -a respectively imply that the relativized covert head nouns relate to 3MS entities which serve as subjects of the respective structures. Although the relative verbs carry object affixes too, the vacuous relativized noun phrases cannot be perceived to be objects. This is because of the fact that, in both cases, the object nouns are explicitly mentioned within the given expressions (lidzottsen 'my children' in the Amharic case and jadəsta 'Desta' in the Ezha structure).

By contrast, in the structures of (13b) and (14b), the subject noun phrases are overtly expressed. Thus, we cannot argue that the covert relativized nouns are subject noun phrases regardless of the fact that the relative verbs bear both subject and object agreement affixes. Consequently, it becomes apparent that the vacuous relativized noun phrases in both structures relate to object noun constituents. These covert nouns are traced by taking into account the object agreement affixes attached to the corresponding relative verbs ( $-w$ of jaballatțifwn in Amharic and - $n$ of jak ${ }^{\text {'w }} \partial t t^{\prime} \partial r \partial n$ in Ezha).

Finally, the constructions (13c) and (14c) depict that the covert relativized nouns are oblique constituents. Here, even if the relative verbs of both languages carry subject agreement suffixes, the vacuous relativized elements cannot be subject noun phrases due to the fact that subject noun phrases are already in place. Nor can we argue that the relativized position could be occupied by object noun phrases. This would be ruled out by the fact that the relative verbs in both Amharic and Ezha do not presuppose any object as they are intransitive (hed-in the Amharic example and war-in the Ezha case both of which mean 'go'). Hence, it is clear that the covert relativized head nouns are oblique constituents which are implied by the applicatives together with the terminal $3 \mathrm{MS}$ suffixes attached to the relative verbs $(-b b-\partial t$ of jahedabbat in the Amharic structure and $-\beta^{w}-a$ of jawara $\beta^{w}$ a in the 
Ezha expression).

Generally, as noted earlier, the identity of covert head nouns in headless relative clauses of both Amharic and Ezha is recovered by considering the agreement markers attached to relative verbs. This, however, does not guarantee the exact reference of the head nouns per se in both languages. As such, discourse context becomes mandatory in order for the entities referred to by the covert head nouns to be specifically understood.

\section{Conclusion}

This article deals with the structure of relative clauses in Amharic and Ezha from the perspective of typological comparison. The descriptions have been made based on the data gathered through introspection for Amharic, and mainly through elicitation by involving native speakers augmented by recording spontaneous speech (free narratives) for Ezha.

In both languages under concern, two major typological categories of relative clauses are identified: headed and headless. Besides, both of the languages are typologically characterized by the absence of relative pronouns. Relativization is carried out by using the morpheme ja- in perfective constructions for both Amharic and Ezha. However, the two languages behave differently when it comes to imperfective conjugations. Amharic expresses relativization in the imperfective structures by using the relativizer imm-, whereas Ezha employs no such an overt relative clause marker in the imperfective constructions. Besides, unlike the case in Amharic, no relativizer overtly appears on negative relative verbs of Ezha; even the one attested to occur on affirmative perfective verbal bases disappears in situations where the relative verb becomes negative. These two phenomena (the absence 
of a relativizer in the imperfective and negative relative verbs of Ezha) are found out to be the sole distinguishing features of the two languages in terms of relativization.

In both Amharic and Ezha, headed relative clauses are found out to be prenominal as the relative clauses precede the head nouns they are meant to modify. In addition, in both languages, the relative verbs consistently appear as the last constituents of the relative clauses, and they exhibit concord with the corresponding relativized head nouns. The head nouns to be modified (which are explicitly indicated in headed relative clauses and implicitly implied by agreement markers in headless relative clauses) in both Amharic and Ezha could relate to the subject, object, oblique or possessor noun constituents of the respective relative clauses.

In conclusion, the two target languages under comparison are found out to have highly convergent ways of expressing relativization. The convergence ranges from the absence of relative pronouns to the application of formally identical bound relative markers in the perfective conjugations. The only divergent features attested with reference to the relativization phenomena in the two languages are that Amharic employs an overt relativizer imm- in the imperfective, while Ezha does not make use of any phonetic form to mark relative clauses in imperfective structures, hence, zero marking; and that Ezha, unlike Amharic, does not employ any overt relativizer (even in the perfective verbal bases) in negative relative verbs. 
52 Typological Comparison of Relativization in Amharic and Ezha

\section{References}

Amare, G. 2009. Argobba Verb Morphology and Syntax: A Documentation with Head-driven Phrase Structure Grammaras Analytic Framework. Ph. D. Dissertation, NTNU.

Assefa, E. 2014. Descriptive Grammar of Ezha: A Central West Gurage Language, Ethio-Semitic. Unpublished Ph.D. Dissertation, Addis Ababa University.

Assefa, E. 2017. Multifunctional Morphemes ja- and - $m$ in Ezha: An Ethio-Semitic Language. Macrolinguistics 5.6, 24-36.

Givon, T. 1984. Syntax: A Functional-Typological Approach II. Amsterdam: John Benjamins Press.

Grimes, B. 2003. Ethnologue: Languages of the World. Dallas, TX: Summer Institute of Linguistics and the University of Texas at Arlington.

Hetzron, R. 1977. The Gunnan Gurage Languages. Naples: Instituto Oriental di Napoli.

Keenan, E. \& B. Comrie. 1977. Noun Phrase Accessibility and Universal Grammar. Linguistic Inquiry 8, 63-99.

Mazengia, S. 2015. Nominalization via Verbal Derivation: Amharic, Tigrinya and Oromo (A Contrastive Study). Wiesbaden: Harrassowitz.

Meyer, R. 2006. Wolane: Descriptive Grammar of an East Gurage Language (EthioSemitic). Koln: Rudiger Koppe Verlag.

Meyer, R. 2011. Gurage. In S. Weninger (ed.), The Semitic Languages: An International Handbook 1220-1256. Berlin: De Gruyter Mouton.

Payne, T. 1997. Describing Morphosyntax: A Guide for Field Linguistics. Cambridge: CUP.

de Vries, M. 2001. Patterns of Relative Clauses. Journal of Linguistics in the Netherlands 18.1, 231-243. 